\title{
An Analysis of Household's Yogurt Consumption in Turkey
}

\author{
${\text { GEZGINC Yekta }{ }^{1, *}, \text { AKBAY Cuma }}^{2}$ \\ ${ }^{1}$ Department of Food Engineering, Kahramanmaras Sutcu Imam University, Kahramanmaras, Turkey \\ ${ }^{2}$ Department of Agricultural Economics, Kahramanmaras Sutcu Imam University, Kahramanmaras, Turkey \\ *Corresponding author: yekgan@ksu.edu.tr
}

Received April 13, 2015; Revised May 06,2015; Accepted May 13, 2015

\begin{abstract}
The objective of this study is to investigate specific consumer and household characteristics that affect consumption decision of yogurt, by using a cross-sectional survey data from 8549 households in Turkey. This study showed that about $81.8 \%$ of the households consume fluid milk and $78 \%$ of the households consume yogurt on a monthly basis. The results indicated that socioeconomic and demographic characteristics of households such as household income, household size, education, age, working status and gender of household head and, residential areas (rural-urban) were statistically significant factors and play an important role on yogurt consumption among Turkish households. Results from these analyses are used to suggest techniques for marketing yogurt consumption to specific segments of consumer population. Moreover, this research provides a profile of households that consume and probably spend more on yogurt.
\end{abstract}

Keywords: yogurt, consumption, nutrition, household survey data, Turkey

Cite This Article: GEZGINC Yekta, and AKBAY Cuma, "An Analysis of Household's Yogurt Consumption in Turkey.” Journal of Food and Nutrition Research, vol. 3, no. 4 (2015): 285-289. doi: 10.12691/jfnr-3-4-9.

\section{Introduction}

Yogurt is the major component in the dairy industry and has been claimed to have many health benefits. There is moderate quality evidence to support the idea that consumption of dairy products, including yogurt may reduce the risk of high blood pressure. However, the precise mechanism for this effect is not fully understood. And the word "Yogurt" is derived from the Turkish word "yogurut" which first appeared in the $8^{\text {th }}$ century [1]. But today, various names are used and refer to tart, thick milk or similar products. Yogurt is one of the oldest and the most popular fermented dairy products in the world. And it has gained widespread consumer acceptance as a healthy food [2]. Therefore, yogurt is nutritionally rich in protein, calcium, vitamin D, riboflavin, vitamin B6 and vitamin B12. It has nutritional benefits beyond those of milk. First off, human body needs to have a healthy amount of good bacteria in the digestive tract, and many different types of yogurt are made using active, good bacteria. One of the words you'll be hearing more of in relation to yogurt is "probiotics" which literally refers to living organisms that can result in a health benefit when eaten in adequate amounts [3]. Numerous health benefits beyond its nutritional value have been associated with consuming yogurt. Scientists have found that the intake of yogurt with active cultures may aid digestion, ease diarrhea, boost immunity, fight infection and protect against cancer $[4,5,6]$. These specific health benefits depend on the strain and viability of the culture in yogurt [7].
In addition, yogurt has more amount of calcium, which helps the body to improve the strength of muscles and bones. Calcium is needed throughout life, but most people don't get enough in their diets. And across the board, the consumption of calcium-rich dairy products tends to decrease as people age $[8,9]$. The recommended daily milk or yogurt consumption is about $200-400 \mathrm{ml}$ for adults and $600-800 \mathrm{ml}$ for children and pregnant women. Besides the obvious nutritional benefits, consumption of yogurt also shows promising health benefits for certain gastrointestinal conditions, such as lactose intolerance and diarrheal diseases. Thus, the popularity of yogurt has increased due to its perceived health benefits. Health promoting attributes of consuming yogurt containing live and active cultures are well-documented [7,10,11].

According to the research, it is determined that $78 \%$ of the families purchase and consume yogurt in Turkey. While yogurt consumption per capita in Turkey is almost same as consumption in the Netherlands, France and Germany, it is higher than the other European and American countries such as the United States, Canada and Brazil. The average amount of yogurt consumed per person in one year in Turkey is about 35.2 liters This amount is 35.7 liters in Netherlands, 35.0 liters in France, 34.6 liters in Germany, 25.3 liters in Spain, 12.7 liters in England, 12.5 liters in Hungary, 6.8 liters in Romania, 15.3 liters in Russia, 7.7 liters in the U.S., 11.0 liters in Canada and, 06.4 liters in Brazil [12,13].

In thousands of years, yogurt has also been an indispensible element of Turkish tables. It is consumed plain or as a side dish, and it is a crucial part of the Turkish cuisine. Yogurt is used to make soups, sweets, 
and the favorite drink ayran, which is made by mixing water and salt $[14,15]$.

Yogurt production in Turkey increased by $2.7 \%$ in 2013 to 1.1 million tons. While the export of yogurt and ayran was 5641 tons in 2007, it increased to 7630 tons in 2013. On the other hand, ayran and yogurt import was 13 tons in 2007, and reached to 47 tons in 2012 [16].

There are several previous researches that are focused on yogurt consumption [17,18], yogurt consumption habits[19] and positive effects of yogurt consumption on health $[20,21,22,23]$. The difference of this study with others is the disclosure of the main factors affecting yogurt consumption of household by investigating the socioeconomic and demographic factors affecting on the consumers yogurt consumption behaviors in Turkey.

\section{Materials and Methods}

The data utilized in this study was Household Budget Survey done through Turkish Statistical Institute (TUIK) in 2008. This survey was conducted with about 8549 households that are selected through stratified and twostaged cluster sampling method. The data consist of household income, food expenditures, yogurt consumption as well as households' socioeconomic and demographic characteristics.

In this research, Chi-square analysis was used to examine the factors affecting on the household yogurt consumption decision and preferences. Chi-square $(\chi 2)$ test is a nonparametric statistical analysis method often used in experimental study where the data consist in frequencies or 'count' as distinct from quantitative data obtained from measurement of continuous variables such as income, age and, consumption. The test assumes that a household is faced with making choices between two alternatives: consuming or not consuming yogurt.

The data consist of household income, food expenditures, yogurt consumption as well as households' socioeconomic and demographic characteristics such as household size, age, education, gender and marital and working status of the head of household and, presence of children.

\section{Results and Discussion}

According to the survey results, $69.7 \%$ of households live in urban areas while $30.3 \%$ live in rural areas (Table 1). The average size of a household is 3.9 persons and the share of the households that have less than 4 children is $71.4 \%$. The share of the households that have members under 15 years old is $56.1 \%$. $88.6 \%$ of the household heads are men, $68.3 \%$ of them work and $88.3 \%$ are married. The average age of the household head is 47.8 and the rate of those older than 50 is $41.7 \%$. $58.9 \%$ of the survey participants are literate or graduated from primary school, $10.9 \%$ graduated from secondary school, 18.3\% graduated from high school and $11.9 \%$ graduated from university. The households were divided into five income groups $20 \%$ each.

According to consumption data, $81.8 \%$ of the households consume milk and $78 \%$ of the households consume yogurt (Table 1). In Turkey, the share of yogurt expenditure out of total milk and milk products spending is approximately $26.57 \%$, while this share is determined as $3.01 \%$ out of total food expenditures [24].

Table 1. Socio demographic characteristics of households

\begin{tabular}{|c|c|c|}
\hline Socio demographic characteristics of households & Description & Average \\
\hline \multirow{2}{*}{ Residential area of Household } & Rural & 30.3 \\
\hline & Urban & 69.7 \\
\hline \multirow{2}{*}{$\begin{array}{l}\text { Household size } \\
(\text { Average = 3.9) }\end{array}$} & $\leq 4$ & 71.4 \\
\hline & $>4$ & 28.6 \\
\hline \multirow{2}{*}{ Households with a child of less than 6 years of age } & No & 71.2 \\
\hline & Yes & 28.8 \\
\hline \multirow{2}{*}{ Households with a child of under fifteen years of age } & No & 43.9 \\
\hline & Yes & 56.1 \\
\hline \multirow{5}{*}{ Household income group } & Lower-income households & 20.0 \\
\hline & Lower to middle income households & 20.0 \\
\hline & Middle-income households & 20.0 \\
\hline & Middle to higher income households & 20.0 \\
\hline & Higher-income households & 20.0 \\
\hline \multirow{2}{*}{ Gender of the household head } & Male & 88.6 \\
\hline & Female & 11.4 \\
\hline \multirow{2}{*}{ Working status of the household head } & Unemployed & 31.7 \\
\hline & Working & 68.3 \\
\hline \multirow{2}{*}{ Marital status of the household head } & Single & 11.7 \\
\hline & Married & 88.3 \\
\hline \multirow{4}{*}{ Age of household head (Average= 47.8) } & $<30$ & 7.3 \\
\hline & $30-39$ & 24.9 \\
\hline & $40-49$ & 26.1 \\
\hline & $50+$ & 41.7 \\
\hline \multirow{4}{*}{ Education level of the household head } & Illiterate or primary school graduate & 58.9 \\
\hline & Secondary school graduate & 10.9 \\
\hline & High school or equivalent graduate & 18.3 \\
\hline & University graduate & 11.9 \\
\hline \multirow{2}{*}{ Milk consumption status } & Not consume yogurt & 18.2 \\
\hline & Consume yogurt & 81.8 \\
\hline \multirow{2}{*}{ Yogurt consumption status } & Not consume yogurt & 22.0 \\
\hline & Consume yogurt & 78.0 \\
\hline
\end{tabular}


The correlation between the yogurt consumption of the households and consumers' socioeconomic and demographic characteristics can be shown in Table 2. The results show that there is a significant relationship between the characteristics of the household and the yogurt consumption decision. As it can be seen according to the Chi Square test results, 11 variables used in the analysis are considered as statistically important at $5 \%$ or $1 \%$ level.

\begin{tabular}{|c|c|c|c|c|c|}
\hline & & \multicolumn{3}{|c|}{ Yogurt Consumption } & \multirow[b]{2}{*}{$\begin{array}{c}\text { Chi-Square } \\
\text { (P-value) }\end{array}$} \\
\hline & & No consuming & Consuming & Total & \\
\hline All households & All households & 22.0 & 78.0 & 100.0 & \\
\hline \multirow{2}{*}{ Residential area } & Rural & 30.9 & 69.1 & 100.0 & \multirow{2}{*}{$172.13(0.000)$} \\
\hline & Urban & 18.1 & 81.9 & 100.0 & \\
\hline \multirow{2}{*}{ Household size } & $\leq 4$ & 22.6 & 77.4 & 100.0 & \multirow{2}{*}{$\begin{array}{c}4.50 \\
(0.034)\end{array}$} \\
\hline & $>4$ & 20.5 & 79.5 & 100.0 & \\
\hline \multirow{2}{*}{ Number of persons under six years } & No & 23.2 & 76.8 & 100.0 & \multirow{2}{*}{$18.64(0.000)$} \\
\hline & Yes & 18.9 & 81.1 & 100.0 & \\
\hline \multirow{2}{*}{ Number of persons under fifteen years } & No & 24.1 & 75.9 & 100.0 & \multirow{2}{*}{$17.88(0.000)$} \\
\hline & Yes & 20.3 & 79.7 & 100.0 & \\
\hline \multirow{5}{*}{ Household income group } & Lower-income & 34.5 & 65.5 & 100.0 & \multirow{5}{*}{$272.78(0.000)$} \\
\hline & Lower to middle income & 24.4 & 75.6 & 100.0 & \\
\hline & Middle-income & 20.8 & 79.2 & 100.0 & \\
\hline & Middle to higher income & 17.8 & 82.2 & 100.0 & \\
\hline & Higher-income & 12.3 & 87.7 & 100.0 & \\
\hline \multirow{2}{*}{ Gender of household head } & Male & 21.5 & 78.5 & 100.0 & \multirow{2}{*}{$\begin{array}{c}9.51 \\
(0.002)\end{array}$} \\
\hline & Female & 25.8 & 74.2 & 100.0 & \\
\hline \multirow{2}{*}{ Working status of household head } & Unemployed & 20.8 & 79.2 & 100.0 & \multirow{2}{*}{$15.79(0.000)$} \\
\hline & Working & 24.6 & 75.4 & 100.0 & \\
\hline \multirow{2}{*}{ Marital status of household head } & Single & 24.8 & 75.2 & 100.0 & \multirow{2}{*}{$\begin{array}{c}5.13 \\
(0.024)\end{array}$} \\
\hline & Married & 21.6 & 78.4 & 100.0 & \\
\hline \multirow{4}{*}{ Age of household head } & $<30$ & 24.0 & 76.0 & 100.0 & \multirow{4}{*}{$10.09(0.018)$} \\
\hline & $30-39$ & 19.7 & 80.3 & 100.0 & \\
\hline & $40-49$ & 22.1 & 77.9 & 100.0 & \\
\hline & $50+$ & 22.9 & 77.1 & 100.0 & \\
\hline \multirow{4}{*}{ Education level of household head } & Illiterate or elementary school graduate & 24.7 & 75.3 & 100.0 & \multirow{4}{*}{$67.29(0.000)$} \\
\hline & Secondary school graduate & 20.7 & 79.3 & 100.0 & \\
\hline & High school graduate & 19.2 & 80.8 & 100.0 & \\
\hline & University graduate & 13.9 & 86.1 & 100.0 & \\
\hline \multirow{2}{*}{ Milk consumption status } & No consuming milk & 36.9 & 63.1 & 100.0 & \multirow{2}{*}{$248.98(0.000)$} \\
\hline & Consuming milk & 18.6 & 81.4 & 100.0 & \\
\hline
\end{tabular}

With respect to demographic characteristics of households; household size has a positive and statistically important affect on yogurt consumption $\left(X^{2}=4.50\right.$; $p=0.034)$. According to the survey results, large families consume more yogurt than small families do. Several other studies also found to show that the household size has a positive effect on the decision for buying dairy products $[25,26]$.

The result indicates that the degree of urbanization has an important role on consuming yogurt and urbanization also contributes to the increase of expenditure for yogurt. According to the independent Chi-Square test results, it was found that the people that live in urban areas consume more yogurt than those live in rural areas. $\left(X^{2}=172.13\right.$; $p=0.000)$. The rural consumers generally consume raw (unpasteurized, unpackaged) milk. These consumers tend to have low income and to be illiterate. Urban consumers, on the other hand, have higher incomes and higher level of education compared with rural consumers and consume more sterilized (packed) milk. In rural areas, consumers usually make their own yogurt but those who purchase their yogurt pay attention to its packaging the most. In rural areas, consumers who make their own cheese have mid - level income and primary school education. In a similar study made by Ayar and Nizamlığlu [25] and Akbay and Tiryaki [27], it is also found that the yogurt consumption of households in urban areas is higher than those living in rural areas.

Milk is the source of nutrition which has protein, calcium, vitamins, iron as both macro- and micro-nutrients and other minerals that are required in every stage of life. It is known as important for that especially between the childhood, pregnancy and old age periods for bone health [28]. According to the survey results, the yogurt consumption in households that have children under the 6 years old was higher compared to the others. $81.1 \%$ of these families consume yogurt while this rate is $76.8 \%$ for the families without children under 6 years of age $\left(X^{2}=18.64 ; p=0.000\right)$. Likewise, the yogurt consumption of households having individuals younger than 15 years old is higher $(79.7 \%)$ than others $(75.9 \%) \quad\left(X^{2}=17.88\right.$; $p=0.000$ ).

Household income is the most important variable affecting the yogurt consumption among families [26,29]. Households were ranked by monthly disposable income and divided into five income groups. For example, the 
lowest income group corresponds to the bottom 20 per cent of the sample. According to results, the relationship between household total income and the yogurt consumption are found to be positive and statistically significant $\left(X^{2}=272.78, p=0.000\right)$. For example, the consumption percentage of the families ranking in lowest income households was $65.5 \%$ while this proportion becomes $87.7 \%$ for the highest income households. This outcome is consistent with the previous dairy consumption researches done by Boniface and Umberger [18], Bus and Worsley [30], Jensen et al. [31], Robb et al. [32] and Yildiz Tiryaki and Akbay [33].

Similarly, according to Chi-Square test result, there is a positive correlation between education level of household head and yogurt consumption $\left(X^{2}=62.29, p=0.000\right)$. The yogurt consumption rises with higher education level. For example, $86.1 \%$ of the university graduates consume yogurt while this rate is $75.3 \%$ among the primary school graduates. Previous study showed that there is also a positive relationship between the education and the milk consumption of consumers [33].

The results of analysis shows that men consume more yogurt than women $\left(X^{2}=9.51, p=0.002\right)$. The relationship between the respondents' working status and their yogurt consumption is negative. $79.2 \%$ of unemployed people consume yogurt while this rate is $75.4 \%$ among employed people $\left(X^{2}=15.79, p=0.000\right)$.

According to the results, there is a positive correlation between yogurt consumption and marital status. Married persons consume more yogurt than the singles $\left(X^{2}=5.13\right.$, $p=0.024)$. Moreover, there is a positive relationship between milk consumption and yogurt consumption of the households $\left(X^{2}=248.98, p=0.000\right)$.

\section{Conclusions}

Yogurt is a convenient food to provide multiple health benefits, which is fuelling its rising popularity. There are not many economic studies that focus primarily on yogurt consumption. This paper aims to fill the gap on yogurt consumption habits of households as well as the socioeconomic and demographic factors affecting household consumption patterns. According to the findings, average household size is 3.9 person and $78 \%$ of them purchase yogurt. The percentage of yogurt expenditure in total milk and milk products was about $26.57 \%$ in Turkey. On the other hand, share of yogurt expenditure on total food expenditure was about 3.01\%. Households increase their yogurt consumption when their income level increases.

The research shows that there are statistically significant relationships between the yogurt consumption and consumers' socio-economic and demographic characteristics. In respect of the Chi-Square test results, most of the factors such as household income education level, gender, age and, marital status of the head of household are found to be statistically important factors on yogurt consumption.

Currently, many companies in the yogurt market differentiated themselves with branding and packaging to continue on their production. The existence of these firms in yogurt sector brings a competition along but both the branding and packaging of yogurt are not sufficient for consumers.
These firms should take customer demands into consideration to survive and at the same time, as private sector, they should make an attempt to increase yogurt consumption. The consumption of branded products in the sector is very low. This can only be solved if the branded yogurt market develops; marketing activities to make the consumers conscious take place and the retail industry sells only the appropriate brands in terms of food codex.

The profitability of the sector is quite low. The firms investing in branded products should compete under the same conditions as the generic manufacturers. The price competition causes the instability since the costs vary.

The yogurt market and yogurt innovation require a comprehensive look at the market for yogurt, both in Turkey and globally. Readers will learn about demographics and socioeconomic factors affecting yogurt consumption, and information on consumption habits; and the new, engaging ways in which yogurt marketers are connecting with customers.

\section{References}

[1] Rasic, J.L., Kurman, J. A., "Yoghurt, fermented fresh milk products”, Technical Dairy Publishing House, Copenhagen, Denmark, 1978, 11-13.

[2] Mckinley, M.C., "The nutrition and health benefits of yoghurt", International Journal of Dairy Technology. 58(1), 1-12, Feb. 2005

[3] Cheng, H., "Volatile Flavor Compounds in yogurt”, Critical Reviews In Food Science and Nutrition. 50, 938-950, Nov. 2010.

[4] Chandra, R.K., "Effects of Lactobacillus on the incidence and severity of acute rotavirus diarrhea in infants. A prospective placebo-controlled double-blind study”, Nutrition Research. 22, 65-69, Jan. 2002.

[5] Adam, A.C., Rubio-Texeira, M., Polaina, J., "Lactose: The milk sugar from a biotechnological perspective”. Critical Reviews In Food Science and Nutrition. 44, 553-557, Feb. 2004

[6] Adolfsson, O., Meydani, S. N., Russell, R. M., "Yogurt and gut function”. The American Journal of Clinical Nutrition. 80, 245256, Aug. 2004.

[7] Chandan, R.C. "Manufacturing yogurt and fermented milks", Blackwell Publishing. Oxford, USA, 89-117, 2006.

[8] Davies, K.M., Heaney, R.P., Recker, R.R., Lappe, J.M., Bargerlux, M.J., Rafferty, K., Hinders, S., "Calcium intake and body weight”, The Journal of Clinical Endocrinology and Metabolism. 80, 46354638, Dec. 2000.

[9] Wang H, Livingston, K.A., Fox, C.S., Meigs, J.B., Jacques, P.F., "Yogurt consumption is associated with better diet quality and metabolic profile in American men and women”, Nutrition Research. 33,18-26, Oct. 2013.

[10] Meydani, S.N., Ha, W.K., "Immunologic effects of yogurt". American Journal of Clinical Nutrition. 71, 861-872, Apr. 2000.

[11] Isolauri, E., Kirjavainen, P.V., Salminen, T., " Probiotics: role in the treatment of intestinal infection and inflammation?” Gut. 50, 54-59, 2002.

[12] Anonymus, "Global yoghurt consumption per capita and per year”. http://nutrijournal.danone.com/en/articles/stories /global-yoghurtconsumption-per-capita-and-per-year/2013.

[13] Anonymus, http://www.capital.com.tr/makro-ekonomi/kisibasina/hesabinin-gucu-haberdetay-2015b.

[14] Akın, N., Rice, P., "Main yogurt and related products in Turkey". Cultured Dairy Products Journal. 29, 23-29, Aug.1994.

[15] Anonymus, http://www.turkishculture.org/culinaryarts/cuisine/yogurt-304.htm?type=1.2015a.

[16] Muehlhoff, E., Bennett, A., McMahon, D. "Milk and dairy products in human nutrition”. Food And Agriculture Organization of The United Nations, 11-35. 2013

[17] Bektaş, F., Davran, M.K., "Changes on food consumption behavior and rural development”. VI. Ulusal Sosyoloji Kongresi. Aydın. 764-786, Oct. 2009.

[18] Boniface, B., Umberger, W.J., "Factors influencing Malaysian consumers' consumption of dairy products”. 56th AARES Annual Conference, Fremantle, Western Australia, Feb. 2012. 
[19] Dogan, S., Yildız, O., Eyduran, E., Kose, S., "A study on determination of functional food consumption habits and awareness of consumers in Turkey”. Bulgarian Journal of Agricultural Science, 17, 246-257, Feb. 2011.

[20] Baysal, A., “Nutrition”. Hatiboğlu Yayınevi, Ankara, Türkiye, 12-16, 2002

[21] Duyff, R.L., "Complete Food and Nutrition Guide" The American Dietetic Association's. John Wiley\& Sons Inc, New Jersey, 112, 536-542, 2003.

[22] Plessas, S., Bosnea, L., Alexopoulos, A., Bezirtzoglou, E., "Potential effects of probiotics in cheese and yogurt production". Engineering in Life Sciences, 12, 433-440, Mar. 2012.

[23] Wang, H, Livingston, K.A., Fox, C.S., Meigs, J.B., Jacques, P.F. "Yogurt consumption is associated with better diet quality and metabolic profile in American men and women". Nutrition Research. 33, 18-26, Dec. 2012.

[24] TUIK, www.tuik.gov.tr. Milk and Milk Products Expenditures 2008. [Accessed Dec. 2014].

[25] Ayar, A., Nizamlığlu, M., "Sociodemographic factors and consumers characteristics effecting milk and milk products". Glda ve Yem Bilimi-Teknolojisi, 1, 25-31. Jan. 2002.

[26] Phuong, N.V., Cuong, T. H., Mergenthaler, M., "Dairy products expenditure pattern in Vietnam: effects of household characteristics on expenditure for dairy products". Gewisola, Schriftlicher Beitrag anlässlich der 54. Jahrestagung der
Gesellschaft für Wirtschafts- und Sozialwissenschaften des Landbaues, Göttingen, Sep. 2014.

[27] Akbay, C., Tiryaki, Y, G., "Unpacked and Packed Fluid Milk Consumption Patterns and Preferences in Turkey”. Agricultural Economics, 38, 9-20, Jan. 2008.

[28] Weinsier, R.L., Krumdieck, C.L., "Dairy foods and bone health: examination of the evidence". The American Journal of Clinical Nutrition, 72, 681-689. 2000.

[29] Dong, D., Kaiser, H., "Studying Household Purchasing and Nonpurchasing Behaviour for a Frequently Consumed Commodity: Two Models”. Applied Economics, 40, 1-11, May. 2008.

[30] Bus, A.E.M., Worsley, A., "Consumers` Health Perceptions of Three Types of Milk: A Survey In Australia”. Appetite, 40, 93-100. 2003.

[31] Jensen, H. H., Kesavan, T., Johnson, S. R., "Measuring the impact of health awareness on food demand". Review of Agricultural Economics, 14, 299-312, July. 1992.

[32] Robb, C.A., Reynolds, L.M., Abdel-Ghany, M., "Consumer preference among fluid milks: low-fat vs. high-fat milk consumption in the United States”. International Journal of Consumer Studies, 31, 90-94, Jun. 2007.

[33] Tiryaki, Y.G., Akbay, C., “Consumer's Fluid milk Consumption Behaviors in Turkey: An Application of Multinomial Logit Model”. Quality Quantity . 44, 87-98, Jun. 2008. 